\title{
COPS STRATEGY: A STRATEGY TO TEACH WRITING SKILL
}

\author{
Fitri Novia \\ Universitas Islam Ogan Komering Ilir (UNISKI) Kayuagung, Indonesia \\ fi_three02@yahoo.id
}

\begin{abstract}
The purpose of this study was to find out whether or not there was a significant difference in writing achievement between students who were taught through COPS strategy and that of those who were not. The sample of the study was 71 students of SMP N 1 Sungai Pinang Ogan Ilir. Purposive sampling technique was used to select the sample. Written test was used to collect the data which consisted of five topics. T-test was used to analyze the data. Based on the result, it was found that the t-obtained (6.450) was higher than t-table (1.950) and the àvalue $(0.000)$ was lower than $\mathrm{P}_{\text {value }}(0.05)$, the null hypothesis $\left(\mathrm{H}_{\mathrm{o}}\right)$ was rejected and alternative hypothesis $\left(\mathrm{H}_{\mathrm{a}}\right)$ was accepted. It meant that there was a significant difference in writing achievement between students who were taught by through COPS Strategy and that of those were not. Thus, COPS strategy can be used to teach writing skill.
\end{abstract}

Key words: capitalization, overall, punctuation, spelling (COPS) strategy, writing skill.

\section{INTRODUCTION}

Writing; part of communication; is used to express ideas, opinions, thought and feeling in a piece of paper. It is important skill that should be achieved by students. Alber-Morgan, Hessler, and Konrad (2007, p.107) determined that writing is critical for accomplishing many important tasks in and out of school and throughout school. Dunn and and finley (2010, p.33) stated that composing text is an essential skill for students. Assigments, tests, and emailing are a few examples to generate thoughts and put them into prose. To have good composition, it needs some skill. These skills include sentence structure (how to arrange words in a sentence), organization (how to arrange ideas paragraph), and of course, grammar and punctuation (Hogue, 2008, p.2). It means that there are some process in doing writing such as prewriting, organization, writing a draft, revising and editing and produce final product.

However, it is considered difficult activities. According Harris et al (2002, p.111), writing is hard work, and to do it well, a writer must sefl-regulate intricate process. Ghabool (2012, p. 132) says that individuals with writing problems may have difficulties in one or more aspects of writing skill such as proper use of grammar, conventions, punctuation, capitalization, spelling, and some of the basic and initiating aspects of writing. Many students have great difficulty writing. Putting words on paper (or a screen) often seems to mystify young writers. They struggle with a range of questions, both broad and specific, from "What is an essay?" and "Where do I get ideas?" to "What is a topic sentence?" and when they've finished, "How do I know if I've been convincing?" (Schulten, 2010). It means that writing is not easy because students must give attention to some aspects of writing skill such as how to arrange ideas, capitalization, punctuation and spelling.

Since writing is not easy for students so that it challenge for them to produce good composition. The productive writing skill is considered a cognitive challenge, because it helps to assess the language competency, recalling cability and thinking ability (Javed, Juan and Nazli, 2013). Many students who find writing challenging 
are in classrooms that do not effectively incorporate best practices ( Troia and Graham, 2003). According to Dunn and Finley (2010, p.2), for students who struggle with composing text, the writing process can be an ardous challenge which often results in frustation and a final copy which is lower in quality than standards dictate. In addition, these students produce writing that is shorter, less cohesive, and poorer in overall quality (Harris et al, 2002). According to Rouhani, Nafchi, and Ziaee (2016, p.733), poor writing skills can have a destructive effect on higher education and employment.

Moreover, as a teacher has responsible to help students to solve students' problems in writing. Teachers can help students become effective writers by teaching a variety of strategies for carrying out each component of the writing processand by supporting students in applying the strategies until they are able to do so independently.Over time, students will develop a repertoire of strategies for writing. Teachers should explain and model the fluid nature in which the components of the writing process work together, so that students can learn to apply strategies flexibly, separately or in combination when they write (IES, 2012). One of strategy that can be used is COPS strategy.

COPS strategy is acronym of capitalization, overall, punctuation and spelling. The COPS Strategy focuses on editing, and therefore improving, a student's writing (Hopp, 2014). COPS assist writers in organizing editing in the writing process. The student is to reread their essay four times, each time focusing on one of the four points of capitalization, organization, punctuation, and spelling (Mclaughlin, 2004). It helps students focus on different aspects of the writing helping them to look for errors in various criteria areas as they work through the editing process.

Based on Telaumbanua and Hafizh (2013, p. 428-429 ), COPS strategy can increase the students' confidence to create their writing independently and also improve students' motivation during classroom writing activities. Besides, the students will more carefully in writing their writing as an assignment. They will more focus on the mechanic component first such as; capitalization, overall appearance, punctuation and spelling, besides focus on the content also. After that, the teachers have the opportunity to give feedback to make the students more comprehend on what they write latter.

In addition, the objective of this study was to find out whether or not there was a significant difference in writing achievement between students who were taught through COPS strategy and that of those who were not. By using this strategy, hopefully it can improve students' problems in writing skill.

\section{TEACHING WRITING BY USING COPS STRATEGY}

According to Schumaker and Deshler (2009, p.85), the mnemonic device COPS strategy was designed to help students remember the four types of errors they should detect and correct.The strategy involved six steps: (1) Use every other line as you write your rough draft, (2) As you read each sentence, ask yourself the "COPS" questions, (3) When you find an error, circle it and put the correct form above the error if you know it, (4) Ask for help if you are unsure of the correct form, (5) Recopy the paragraph neatly, and (6) Reread the paragraph as a final check. The "COPS questions" related to the four categories of errors the students were to detect and correct (e.g., The "C" question: "Have I capitalized the first word and proper nouns?"). (Please note that our strategy steps were not brief, and, again, a mnemonic device was not created at this time. 
Futhermore, this strategy prompts students to look for in their editing process. After a student thinks they have finished with a piece of writing, they are instructed to read through it four separate times, each time looking for one of the four focuses of COPS. This can help them break it down into more manageable chunks so they can do a better job with their editing (Hopp, 2014).

There are some advantages of using COPS strategy in teaching writing skill Telaumbanua and Hafizh (2013, p.428) :

a. Students can use COPS to self correction as they write using the COPS strategy as a checklist.

b. Students can use COPS as a final editing checklist of a written piece of work before the final draft is written.

c. Students will be more confident to create their writing and collect it as a assignment without ignoring mechanics components in writing.

d. Student also will be more careful to write without ignoring mechanics component in writing.

The stages teaching writing skill by using COPS strategy (Lieneman and Reid, 2009) :

1. Write on every other line to leave room for edits.

2. Read the paper for meaning.

3. Interrogate yourself using COPS strategy:

\begin{tabular}{|c|c|c|c|}
\hline Capitalization & Overall & Punctuation & Spelling \\
\hline $\begin{array}{l}\text { Have them ask } \\
\text { themselves: } \\
\text { - Is the first word } \\
\text { of every } \\
\text { sentence } \\
\text { capitalized? } \\
\text { - Are proper } \\
\text { nouns } \\
\text { capitalized? } \\
\text { - Are there other } \\
\text { words that I } \\
\text { have capitalized } \\
\text { that I shouldn't? }\end{array}$ & $\begin{array}{l}\text { Have them ask } \\
\text { themselves: } \\
\text { - Does it look } \\
\text { neat? } \\
\text { - Is there } \\
\text { enough or } \\
\text { too much } \\
\text { space } \\
\text { between } \\
\text { words? } \\
\text { - Does it } \\
\text { make sense? } \\
\text { - Did I use } \\
\text { complete } \\
\text { sentences? }\end{array}$ & $\begin{array}{l}\text { Have them ask } \\
\text { themselves: } \\
\text { - Is there } \\
\text { punctuation at } \\
\text { the end of } \\
\text { every sentence? } \\
\text { - Does the } \\
\text { punctuation I } \\
\text { used make } \\
\text { sense? } \\
\text { - Do I use other } \\
\text { punctuation, } \\
\text { such as } \\
\text { quotation } \\
\text { marks, } \\
\text { correctly? }\end{array}$ & $\begin{array}{l}\text { Have them ask } \\
\text { themselves: } \\
\text { - Did I spell } \\
\text { all the words } \\
\text { correctly? } \\
\text { - Are there } \\
\text { any words I } \\
\text { should check } \\
\text { that I am } \\
\text { unsure } \\
\text { about? }\end{array}$ \\
\hline
\end{tabular}

4. Take the paper to someone else to proofread

5. Execute a final copy

By teaching students to check for these things before they hand in a paper, their writing has great potential to improve. This can help students to turn in their best possible paper and reduce the amount of errors which their paper contains (Hopp, 2014).

\section{METHODS}

Quasi experimental method was used in this study. The sample of the study was 71 students of SMP N 1 Sungai Pinang Ogan Ilir. Purposive sampling method was used to select the sample. Flipped coin was used to determine the experimental 
group and the control group. Consequently, VII.1 was as a the experimental group and VII.3 was as a the control group. Written-test was used to collect the data which consisted five topics of descriptive text. To find out validity, content validity was used. Inter-raters reliability was used to measure the reliability. Descriptive scoring rubric was used when two raters gave scoring for students' composition. To analyze the data, t-test was used.

\section{FINDINGS AND DISSCUSSION}

Based on the result, it was found that the t-obtained (6.450) was higher than ttable (1.950) and the àvalue (0.000) was lower than $\mathrm{P}_{\text {value }}(0.05)$, the null hypothesis $\left(\mathrm{H}_{0}\right)$ was rejected and alternative hypothesis $\left(\mathrm{H}_{\mathrm{a}}\right)$ was accepted. It meant that there was a significant difference in writing achievement between students who were taught by through COPS Strategy and that of those were not.

\begin{tabular}{lllccc}
\hline \multicolumn{1}{c}{ Method } & Variable & t & Df & Sig (2-tailed) & $\begin{array}{c}\text { Mean } \\
\text { diffrence }\end{array}$ \\
\hline $\begin{array}{l}\text { COPS } \\
\text { Strategy }\end{array}$ & Writing & 6.450 & 69 & .000 & 1.936 \\
\hline
\end{tabular}

By using COPS strategy, students could edit their paragraph to improve their writing skill. Students could write their ideas freely without doubt the mistakes that they did. After they wrote the draft, they reread many times their work then they edited the text by using COPS. By answering each questions from menemonic COPS (Capitalization, overall, punctuation \& spelling), they found the mistakes of their text by circle it, so that they reduced the errors which appeared in their paper.

Futhermore, COPS strategy assisted students in organizing the ideas after edited in the writing process. This strategy helped students to produce their best paragraph because they focused on the point of capitalization, organization, punctuation, and spelling. In addition, students created their paragraph with more confident without ignoring mechanics component in writing. They could use COPS strategy to do self correction. Before they wrote the final draft, they could use COPS strategy as a final editing checklist of a written piece of work. Beside, they could ask another students to proofread with the COPS mnemonic as the rubric in doing editing process. Hence, they got more correction to reduce errors in their work. In conclusion, COPS strategy could improve students' problems in writing skill and it can be used to teach writing skill.

\section{CONCLUSION}

The objective of this study was to find out whether or not there was a significant difference in writing achievement between students who were taught through COPS strategy and that of those who were not. Based on the result, there was a significant difference in writing achievement between students who were taught by through COPS Strategy and that of those were not. COPS strategy assisted students in organizing the ideas after edited in the writing process. Students could use COPS strategy to do self correction and they could ask another students to proofread with the COPS mnemonic as the rubric in doing editing process so that they reduced the errors which appeared in their paper. In conclusion, COPS strategy could improve students' problems in writing skill and it can be used to teach writing skill. 


\section{REFERENCES}

Alber-Morgan, S.R., Hesler, T., \& Konrad, M. (2007). Teaching writing for keeps. Education and Treatment of Children, 30(3), 107-128.

Dunn, M.W., \& Finley, S. (2010). Childrens'struggles with the writing process exploring storytelling, visual arts, and keyboarding to promote narrative story writing. Muticultural education,33-42.

Ghabool, N. (2012). Investigating Malaysian ESL students' writing problems on conventions, punctuation, and language use at secondary school level. Journal of Studies in Education, 2(3), 130-143.

Haris, K.R., Graham, S., Mason, L.H., \& Saddler, B. (2002). Developing selfregulated writers. Theory into practice, 41(2), 110-115.

Hogue, A. (2008). First steps in academic writing. White Plains,NY: Pearson Education, inc.

Hopp, A. (2014). COPS strategy. Available at http://ldlearningstrategies.weebly.com/cops-strategy.html

IES. (2012). Teaching elementary school students to be effective writers. Available

at http://ies.ed.gov/ncee/wwc/publications_reviews.aspx\#pubsearch.

Javed, M., Juan, W,X., \& Nazli, S. (2013). A study of students' assessment in writing skills of the English language. International Journal of Instruction, 6(2), 129-144.

Lienemann, T., Reid, R., \& the IRIS Center. (2009). Written expression: Grades 2-5. Available at http://iris.peabody.van- derbilt.edu/wpcontent/uploads/pdf_case_studies/ics_writex.pdf.

Mclaughlin, D.A. (2004). An assessment of the effectiveness of the POW plus TREE and COPS writing strategies. Master Dissertation. Rowan University.

Rouhani, Y., Nafchi, A.S., \& Ziaee, S.Y. (2016). Applying different interventions to teach writing to students with disabilities: A review study. Theory and Practice in Langauge Studies, 6(4), 733-741.

Schulten, K. (2010). Writing skill and strategies. New York: New York Times.

Shumaker, J.B., \& Deshler, D.D. (2009). Adolescents with learning disabilities as writers: Are we selling them short?. Learning Disabilities research practice, 24(2), 81-92.

Telaumbanua, Y.P., \& Hafizh, M.A. (2013). Using the COPS strategy in teaching writing a narrative text to junior high school students. Journal of English Language Teaching, 2(1), 424-42.

Troia, G.A., \& Graham, S. (2003). Effective writing instruction across the grades: What every educational consultant should know. Journal of Educational and Psychological Consultant, 14(1), 75-89. 